pp. $488-504$

\title{
The Relationship between Perceived Organizational, Perceived Supervisor Support, and Need Achievement to Work Engagement of School Organization
}

\begin{abstract}
Submitted 21/07/20, $1^{\text {st }}$ revision 16/08/20, $2^{\text {nd }}$ revision $23 / 09 / 20$, accepted $10 / 10 / 20$

$$
\begin{gathered}
\text { Richard Andre Sunarjo }{ }^{1} \text {, Innocentius Bernarto }{ }^{2} \text {, Niko Sudibjo }{ }^{3} \text {, } \\
\text { Martin Santoso }
\end{gathered}
$$

Abstract:

Purpose: Many scholars studied the effect of perceived organizational support and perceived supervisor support against work engagement, but the results have shown inconclusive. This study aims to investigate the positive effect of perceived organizational support and perceived supervisor support mediated by need achievement motivation against work engagement.

Design/Methodology/Approach: The data was collected using questionnaires to associates (teachers, non-teachers, management) of an outstanding school in Jakarta, and they were recruited as respondents using a purposive sample method. Partial least square-structural equation modeling (PLS-SEM) analysis was conducted by SmartPLS to analyze the data.

Findings: The study finds that perceived organizational support and perceived supervisor support need achievement motivation as mediator positively and significantly affect work engagement. Perceived organizational support has positively and significantly affected work engagement directly, but perceived supervisor support does not directly affect it.

Practical implications: Practically, this research shown that to improve work engagement by POS and PSS should motivate first the associates on how to achieve the best performance by setting outstanding career opportunities or higher key performance index as challengeable goals.

Originality/value: This research contributes to the job demand-resources' theory when organizations and supervisors show support to their associates by giving job resources, it needs to improve their motivation to achieve the best performance, otherwise, this improvement can not be utilized to reduce job demand and finally cannot improve the work engagement.
\end{abstract}

Keywords: Perceived organizational support, perceived support supervisor, need achievement motivation, work engagement, school organization.

JEL: M13.

Paper type: Research article.

ISSN: 2241-4754, H index 10, Q3.

\footnotetext{
${ }^{1}$ School of Management Universitas Budi Luhur, Jakarta, Indonesia, rasusi2015@gmail.com;

${ }^{2}$ School of Business and Management Universitas Negeri Malang,Malang,

${ }^{3}$ School of Education Universitas Pelita Harapan, Jakarta, Indonesia.

${ }^{4}$ School of Law Universitas Indonesia, Jakarta, Indonesia
} 


\section{Introduction}

Work engagement is a construct becoming a challenge for the business and workforce market, especially in the follow up of the increasing professionalism in all areas of work in various fields, including the educational organization. The use of technology that demands the individual's ability to use it by themselves becomes a challenge for the organization when one associate resigns. This causes the job continuity to break, thus causing a considerable loss for the organization invested along the career path of associates for education (Swarnalatha and Prasanna, 2012). Maslach, Schaufeli, and Leiter (2001) define work engagement as the antithesis of the burn-out where a person with work engagement will be eliminated from the burn-out, as the engaged associates would be energetic and effective with their work, unstressed and the associate enjoy their work as a challenge, based on this definition much research has been done to know the antecedent for this work engagement.

Antecedents were researched a lot by scholars related to work engagement (WE) are the influence of Perceived Organizational Support (POS) and Perceived Supervisor Support (PSS) as predictor work engagement (Burns, 2016). POS and PSS significantly affect an organization's associates' work engagement, but researchers rarely noticed that researchers with McClelland's need achievement motivation (Putra, Cho, and Liu, 2017). Meanwhile, in this disruptive era, with the intense business competition, requiring human resources to show their achievements will get a better chance in their careers, and it can be achieved when the motivation for achievement can be implemented in the organization (Jain, 2019). Therefore, this research will fill in this gap by studying POS and PSS's relationship against work engagement with the need for achievement motivation as a mediator.

The primary purpose of this study is to analyze: (1) Does POS have a positive influence on associates' work engagement? (2) Does PSS have a positive influence on the associates' work engagement? (3) Does POS have a positive effect the need for achievement? (4) Whether PSS have a positive impact on need achievement? (5) Whether need achievement has a positive effect on work engagement and (6) Does POS positively affect PSS? This research's contributions on the practical side will make the practitioners understand how to improve their associates' work engagement related to POS and PSS. It can be established as a countermeasure to fix and prevent the resignation of the associate. On the theoretical side, this new research model contributes to filling in the gap of the inconclusive relationship of POS and PSS against work engagement.

\section{Literature Review}

\subsection{Work Engagement}

According to Schaufeli, Salanova, Gonzales-Roma, and Bakker (2002), the work engagement construct is a positive and fulfilling work-related state of mind with 
three characters. Vigor is characterized as a high level of strength and mental endurance (resiliency) in severe working conditions, a willingness to strive earnestly at work, and persistence in the face of difficulties dedication. Dedication is characterized by a feeling of passion, enthusiasm, inspiration, and pride. Associates always feel challenged and absorbed by work, with full concentration and a deep interest in the work until they feel so challenged that they want to break away from the job. Bakker and Demerouti (2007) researched that work engagement will happen if associates' job resources are more significant than job demand; otherwise, the associates will be burned out. So, the work engagement approached by Schaufelli et al. (2002) as the antithesis of the burn-out aligns with Maslach, Wilmar, Schaufeli, and Leiter (2001) emphasize an individual with work engagement would be spared from the burn-out. Sun and Bunchapattanasakda (2019) emphasize that associates with high work engagement will manifest an active and work-related psychological state in which their perceptions, emotions, and behaviors full of energy and involvement in their organization. They also define that there are three drivers of work engagement that are organizational factors (such as management style and rewards), job factors (work environment, task characteristics), and individual factors (vigor, self-consciousness).

Based on the explanation above, it can be concluded that work engagement is the totality of individual attitudes towards work that are initiated by positive, proactive, fulfilling, and cognitive absorption attitudes, transformed into vigorous affective attitudes. Associates show a work ethic above expectations, and they are always challenged to achieve the best performance, manifested in a dedicated attitude (behavior attitude) that would be spared from the burn-out.

\subsection{Perceived Organizational Support}

POS is defined as a construct that indicates that associates feel that their organization appreciates their contributions and well-being (Eisenberger, Vandenberghe, and Rhoades, 2002; Khrisnan and Mary, 2012). POS is developed from organization support theory; POS will increase associate's confidence that the company will acknowledge and reward their increased performance. The belief will then encourage associates to improve their performance and contribution to the company. POS also improves performance on regular job activities and enhances actions beyond obligation as a profitable associate for the organization (Rhoades and Eisenberger, 2002). POS is determined by effective leadership, Human Resources (HR) strategy such as effective leadership, implementation of beneficial HR rules, desired job conditions, and fair treatment. Top management will provide policies and practices that support the members and be applied by his supervisor through helpful actions and considerately (Eisenberger, Malone and Presson, 2016).

\subsection{Perceived Supervisor Support}

Perceived supervisor support (PSS) is defined as the extent to which associates trust 
supervisors to assess their contributions, assist, and care about their welfare (Cole, Bruch, and Vogel, 2006; Eisenberger et al., 2002; House, 1981), PSS is a general view of members of the organization to supervisors in assessing the contribution of members and giving attention to the well-being of its members (Kottke and Sharafinski, 1988).

PSS also explained how big associates feel that their supervision voluntarily provides resources and assistance so that associates can be better at work (Babin and Boles, 1996). Through PSS, associates assess the role of supervisors or employers directly as the company's agents when the good interaction between the employer and subordinate happens; it will occur positive interactions and increase the engagement of associates in the organization (Burns, 2016).

PSS differs from POS; PSS focuses explicitly on how the supervisor provides its resources for associates with support as an organizational agent, because supervisors act as agents of the organization, who have the responsibility to direct and evaluate the performance of their members, whether associates will see them or not, profitable or not, supportive or not, the orientation of supervisors against them is an indication of the support of the organization (Eisenberger et al. 1986; Levinson 1965). The associate understands that the supervisor evaluations of his/her members and the results are generally conveyed to the management above. This evaluation will affect management perceptions of the organization's members' performance so that in this situation, PSS will contribute to the POS. The strength of this relationship will depend on how large the level of identification of the supervisor about the organization, e.g., for supervisors who seem highly valued and treated well by organizations will be identified in line with the fundamental character of the organization, and this will affect the post (Eisenberger et al., 2002).

\subsection{Need Achievement Motivation}

Although the precise understanding of motivation continues to evolve, most theoretical approaches argue that motivation arises from an internal factor that encourages actions; it is called intrinsic motivation, and external factors from an environment stimulate activity, called extrinsic motivation (Deci and Ryan, 1985). According to Deci and Ryan (1985), one reason for intrinsic motivation is incongruity, and people tend to reduce the incongruity, such as McClelland need achievement motivation, refer to affective-arousal theory, that an optimal discrepancy between a perception and an adaptation level is said to cause a primary emotional response (Deci and Ryan, 1985).

McClelland, Atkinson, Clark, and Lowell (1953) declare that every associate has some needs to compete and motivate each other with the highest goals. The highest goals will become visible if an individual does direct competition with someone else, but it also can be seen based on how well the task was done that it can also be evident in the concern for how well one individual performs his/her job (McClelland 
et al., 1953). Deci and Ryan (1985) also studied motivation as originally defined, achievement motivation as intrinsic motivation because individuals tried to match an internal standard of excellence. However, practically an internal standard can be either intrinsic or internalized, so achieving motivation is extrinsic. Theoretically, Deci and Ryan (1985) define self-determinant theory (SDT) based on the individual to have intrinsic and extrinsic motivation. They indicated that SDT motivation was centralized to autonomous (volitional) and controlled (forced) motivation.

\section{Hypotheses Development}

\subsection{Perceived Organizational Support and Work Engagement}

Refer to Social Exchange Theory (SET) an organization has the expected resources to provide support to their associates to become resources that cannot be replicated as a competency advantage organization (Blau, 1964). The organization's role can be manifested as improved job resources, such as providing resources necessary for associates to solve the problems, giving a supervisor who can assist in the form of solutions-based, providing significant career development, and conducting a dynamic organizational restructuring. Based on the JD-R Theory (Bakker and Demerouti, 2007), job resources' improvement will decrease job demand and improve work engagement.

Cherubin (2012) examined the influence of POS on work engagement. His research wanted to prove whether POS has significantly affected the work engagement with the initial research baseline Eisenberger et al. (1986), which concluded that the POS relationship with work engagement was not necessarily significant, depending on the strong absence of the POS of the associate.

Contrary to Mujiasih (2015) that she resumed, there is a significant and positive influence of POS on work engagement, and as a result, there is a significant and positive correlation between perceived organizational support and work engagement. Mujiasih (2015) emphasizes that organizational culture, such as openness, a supportive attitude, and excellent communication, will have a positive effect on POS; other factors like distributive and procedural justice will strengthen the emotional bonds of employees, and organizations also have a positive impact on the employee's good perception to the organization and finally improves work engagement.

Murty (2017) also researched in Indian organization this relationship between POS on work engagement among managerial positions and concluded that there is a significant and positive relationship. A similar result was concluded by Najeemdeen, Abidemi, Rahmat, and Bulus (2018), with unit analysis an academic staff in the School of Business that shows a significant and positive relationship between perceived organizational support and perceived organizational culture on work engagement. Najeemdeen et al. (2018) emphasized that it is important for university management to have a close relationship with academic staff to feel supported by the 
organization. The academic staff's perception of their management will boost employees' motivation and their willingness to involve themselves in any work. Therefore, POS will be a positive impact on work engagement.

\section{Hypothesis 1: The POS positively affects work engagement.}

\subsection{Perceived Supervisor Support and Work Engagement}

Social exchange theory explained that the full support of supervisors to associates would cause associates to be more passionate, dedicated, and full concentration on their work; this is due to what is given by the supervisor is a manifestation of the organizational policy, so that associates will give reward also for what is given by the supervisor through the organization (Eisenberger et al., 2002; Levinson,1965).

PSS as an antecedent of work engagement proved that a significant correlation against work engagement, PSS had a positive effect on working, means that associates will be more engaged in their work when their supervisor is more supportive (Burns, 2016; Khattak, Batool, Rehman, Fayaz and Asif, 2017). Gülbahar (2020) also researched this relationship for teachers in Turkey's senior high schools. He also emphasized that the PSS of teachers will make more effort to develop their schools because they will be more committed to their organizations.

Supervisors who demonstrate support to their members will have an impact on improving personal resources in the view of their associates, such as giving feedback on the performance, autonomy, professionalism experience sharing if the supports are done continuously, it will increase job resources for the associate, and following JD-R theory it will improve work engagement because of decreasing of job demand (Bakker and Demerouti, 2007; Schaufeli and Salanova, 2007). Therefore, PSS is expected to influence work engagement positively.

\section{Hypothesis 2: The PSS positively affects work engagement.}

\subsection{Perceived Organizational and Need Achievement Motivation}

Karami, Ismail, Wahiza, Badsar (2012) studied POS related to their well-being and their contribution to achievement motivation represented by three-dimension of need achievement, aspiration, mastery, and salience. Aspiration is an orientation to pursue a specific career in such a way that affects a person's values and goals to be achieved, and mastery refers to the tendency for people to continue to improve their skills to complete the task. Salience refers to the degree of one's involvement in careers (Karami and Ismail, 2013). The result showed that POS positively significantly affects aspiration and mastery, so they suggested improving motivation by supporting an organization about work goal achievements such as professionalism, development opportunities, and skill up selected associates authority (Karami et al., 2012). 
Lestariningsih (2017) concluded that POS significantly and positively as a moderator of the relationship of need achievement motivation with performance. The research was implemented in private "A" accredited university lectures in Indonesia. Because of need achievement motivation, these lectures will change the working environment from the individual rivalry to become group motivation; with the moderation POS, they will achieve the best performance (Lestariningsih, 2017). Chen and Shaffer (2017) divided POS as financial, career, and adjustment to associates' needs. Financial POS (related to salary, financial reward) significantly and positively affect controlled motivation. Meanwhile, career and adjustment (related to job transfer policy and practices) POS will affect autonomous motivation (Chen and Shaffer, 2017). Therefore, POS effect needs achievement motivation.

\section{Hypothesis 3: The POS positively affects need achievement motivation.}

\subsection{Perceived Supervisor Support and Need Achievement Motivation}

The relationship of perception associates to supervisor support against need achievement motivation was researched by Karami and Ismail (2013). According to the research, PSS positively and significantly affects aspiration and mastery. However, it is not supported for salience, but they also research the effect on PSS related to the work-life balance of the associates that showed any positively and significantly effects on salience motivation. This research aligned with Gillet, Huart, Colombat, Philippe, and Fouquereau (2013) concluded that PSS significantly and positively affects self-determination motivation, which is needed achievement motivation in this category. Therefore, PSS will affect need achievement motivation. Like this result, Boscha, Herasb, Russoc, Rofcanind, and Grau (2018) studied the relationship supervisor support, especially with the supportive family supervisor, that affects work motivation. They found a significant and positive relationship.

Another implementation was researched by London (1993) that linked achievement motivation with career resilience, as a dimension of career motivation, and concluded that there are significant and positive relationships between PSS and career motivation. The researchers found that career motivation, including support of supervisor for career development and enlarge job structures, giving feedback to the associates, and associates to improve their career plan and train them, will affect associates' performance goals. All these supports will impact the associates and determine their supervisors to empower them and enhance their motivation. Therefore, Perceived supervisor support will affect need achievement motivation.

\section{Hypothesis 4: PSS will positively affect need achievement motivation.}

\subsection{Need Achievement Motivation and Work Engagement}

According to Anokye and Asumeng (2019), psychological capacity (psyche) and achievement motivation against work engagement show no significant relationship 
between achievement motivation and work engagement. They researched a quantitative cross-sectional of 160 micros and small-scale businesses located in Accra, Ghana. Refer to the expectancy-theory of achievement motivation, and it can be explained that basically, an entrepreneur's perception of a business relies on their competence in the face of business challenges. In general, they will not develop a business that lacks a success prospect (Anokye and Asumeng, 2019). In contrast to previous studies that found a significant positive relationship between achievement motivation and work engagement in China, there is a positive correlation between need achievement and work orientation (Hsu, Chen, Yu, and Lou, 2010). Because of the educational organization's risk less than small-scale business, therefore, for educational organization achievement, need achievement motivation will affect work engagement. This research aligned with Gillet et al. (2013) concluded that selfdetermination motivation significantly and positively affects work engagement. Therefore, need achievement motivation will affect work engagement.

\section{Hypothesis 5: Need achievement motivation will positively affect work engagement.}

\subsection{Perceived Organizational and Perceived Supervisor Support}

Eisenberger, Stinglhamber, Vandenberghe, Sucharski, and Rhoades (2002) conclude that there is a positive and significant relationship between PSS and POS; the effect PSS was stronger than POS, so PSS leads POS, associates will be perceived that organization support them when they have well-perceived supervisors support, one reason because of supervisor meet their associates every day, they will have more chance to deliver positive valuation and caring compare with the organization (Eisenberger et al., 2002). Burns (2016) also concludes that POS and PSS had a moderately high correlation. The research concludes that POS is likely to include PSS in that perception of organizational support; it also involves how employees perceive their supervisors' support. Although slightly improve the effect of POS to work engagement, means, the research concluded that PSS improve the perception of the associate of organizational support. Therefore, PSS will affect POS (Burns, 2016). Research of PSS combine with POS did by Shi and Gordon (2020) that studied both constructs' effect on work engagement and psychological capital. They concluded that PSS's relationship positively and significantly with work engagement in the hospitality industry; they also found that associates with High PSS mean the supervisor will deliver resources to the associates when they have difficulties with the task and have higher work engagement.

Hypothesis 6: The POS has a positive effect on PSS.

\section{Research Methodology}

The research was conducted on associates (teachers, non-teachers, management) using a questionnaire implemented in an "XYZ Senior High School" based in Jakarta. The population is about 2000 associates. The sample is taken by a purposive 
method with sample size determined to follow the statement of Hair et al. (2010), which admits that the right sample size is of a total between 150 to 400 , for research using the PLS-SEM approach. It was decided that the study should have around 300 respondents, and then data were analyzed with a statistical analysis of SmartPls 3.2.8 Program.

Figure 1. Research Model

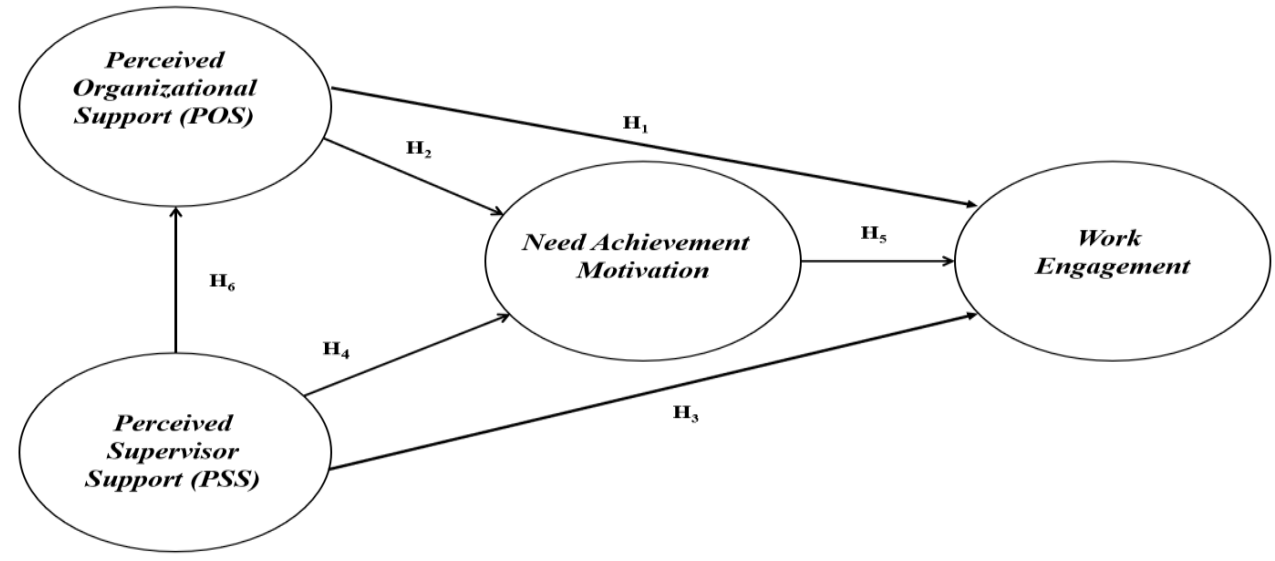

Source: Own study.

Questionnaire items of perceived organization support (POS) and perceived supervisor support (PSS) were adapted from Survey Perceived Organizational Support (SPOS) and Survey Perceived Supervisor Support (SPSS) (Eisenberger et al., 1986; Kottke and Sharafinski, 1988). Work engagement questionnaire items were adapted from Schaufeli et al. 's Utrecht Work Engagement Scale (UWES)-9 (Schaufeli, Bakker, and Salanova 2006). Need achievement motivation (n. Ach) questionnaire items were adapted from Herman's questionnaire of achievement motivation (Herman, 1970). All items were measured using 5 points of Likert scale i.e. $1=$ very disagree, $2=$ disagree, $3=$ neutral, $4=$ agree, and $5=$ very agreed . Furthermore, the instrument is tested for its validity and reliability by the statistical analysis of PLS-SEM at the measurement model stage.

A total of 334 respondents participated in this research. The chosen respondents work in XYZ senior high school, consisting of teachers, non-teachers, and management with one year's service period. The response rate in this research, 95.4 $\%$ of the 350 questionnaires that were delivered and returned. The surveys were done regarding the surveys; all data compiled from the questionnaires were deemed valid and utilized. Regarding the demographic profile of the respondents, out of 334 respondents, 233 respondents are male (69.2\%), while 101 respondents are female $(30.8 \%)$. Furthermore, tenure period composition are 1-2-year: 11.7\%, 3-5 year: $10.5 \%$, 6-10 years: $24.9 \%$, and more than 10 years is $53 \%$. The job group composition is teachers $68.6 \%$, non-teachers $18.2 \%$, management $13.2 \%$. 


\section{Results}

\subsection{Measurement Model}

In this stage, validity and reliability testing are performed before evaluating the structural model, namely, validity test considering Average Variance Extracted (AVE) and loadings factors or outer loadings. The minimum value to be fulfilled for AVE and outer loadings is 0.5, respectively, 0.7 (Sarwono and Narimawati, 2015). The data (Table 1) indicates that the AVE values range from 0.565 to 0.656 , which means that the measurement result is valid. Likewise, the value of the loadings or outer loadings is 0.666 to 0.872 . The value of outer loadings between 0.4 to 0.7 can be retained as long as it can increase AVE's value. Further reliability test is done by calculating the composite reliability $(\mathrm{CR})$. The calculation results show that the composite reliability value is between 0.830 and 0.930 and has been a qualified minimum threshold value of 0.7 (Sarwono and Narimawati, 2015).

Table 1. Outer model analysis

\begin{tabular}{|c|c|c|}
\hline \multicolumn{2}{|r|}{ Construct and Items } & $\begin{array}{c}\text { Outer } \\
\text { Loading }\end{array}$ \\
\hline \multicolumn{3}{|c|}{ Perceived Organizational Support/POS $(A V E=0.583 C R=0.875)$} \\
\hline PO1 & Organization account for my contribution by providing welfare & 0.726 \\
\hline PO2 & $\begin{array}{l}\text { I got appreciation from the organization when working more than } \\
\text { targeted }\end{array}$ & 0.780 \\
\hline PO3 & The Organization correctly pay attention to my welfare & $\mathbf{0 . 7 7 0}$ \\
\hline $\mathrm{PO} 4$ & $\begin{array}{l}\text { Organizations are noticing/caring about my general satisfaction in } \\
\text { the workplace. }\end{array}$ & 0.763 \\
\hline PO5 & Organizations are proud of my achievements in the workplace. & 0.775 \\
\hline \multicolumn{3}{|c|}{ Perceived Supervisor Support/PSS (AVE=0.626, CR=0.921) } \\
\hline PSS1 & My supervisor pays attention to my welfare & 0.832 \\
\hline PSS2 & $\begin{array}{l}\text { I got appreciation from my supervisor when working more than } \\
\text { targeted }\end{array}$ & 0.838 \\
\hline PSS3 & The supervisor correctly pays attention to my welfare & $\mathbf{0 . 8 2 0}$ \\
\hline PSS4 & $\begin{array}{l}\text { Although I did the best job may be the supervisor didn't notice me } \\
\text { with the awards, I needed }\end{array}$ & 0.754 \\
\hline PSS5 & $\begin{array}{l}\text { Supervisor pay attention/care about my general satisfaction in the } \\
\text { workplace. }\end{array}$ & $\mathbf{0 . 8 3 3}$ \\
\hline PSS6 & $\begin{array}{l}\text { The Supervisor showed only a little attention to me in my work } \\
\text { although I reached the target }\end{array}$ & 0.674 \\
\hline PSS7 & Supervisor is proud of my achievements in the workplace. & 0.776 \\
\hline \multicolumn{3}{|c|}{ Need Achievement Motivation/n.Ach $(A V E=0.565, C R=0.900)$} \\
\hline NA1 & In working, a colleague looked at me as a hard worker & 0.666 \\
\hline NA2 & I need to prepare everything well for the success of a project/task & 0.747 \\
\hline NA3 & When I work, the demands I make on myself are very high & 0.706 \\
\hline NA4 & $\begin{array}{l}\text { When lecturers give lectures, I usually try to pay attention well } \\
\text { and make a good impression }\end{array}$ & 0.804 \\
\hline
\end{tabular}


The Relationship between Perceived Organizational, Perceived Supervisor Support, and Need Achievement to Work Engagement of School Organization

498

\begin{tabular}{|l|l|c|}
\hline NA5 & $\begin{array}{l}\text { If I haven't reached my goal and not done a good job, then I keep } \\
\text { doing my best to reach the goal. }\end{array}$ & $\mathbf{0 . 8 3 8}$ \\
\hline NA6 & $\begin{array}{l}\text { I want to do many things for work that requires great } \\
\text { responsibility, }\end{array}$ & $\mathbf{0 . 7 7 7}$ \\
\hline NA7 & When doing something difficult I do not give up too soon & $\mathbf{0 . 7 1 0}$ \\
\hline Work engagement/WE $(\boldsymbol{A} \boldsymbol{V E}=\mathbf{0 . 6 5 6}, \boldsymbol{C R}=\mathbf{0 . 9 3 0})$ & $\mathbf{0 . 8 0 4}$ \\
\hline WE1 & At my workplace, I feel full of energy. & $\mathbf{0 . 7 8 9}$ \\
\hline WE2 & At my job, I feel strong and spirit & $\mathbf{0 . 8 7 2}$ \\
\hline WE3 & I am enthusiastic about my work. & $\mathbf{0 . 8 0 4}$ \\
\hline WE4 & My work inspires me & $\mathbf{0 . 8 0 7}$ \\
\hline WE5 & When I woke up in the morning, I felt like I was working & $\mathbf{0 . 8 0 0}$ \\
\hline WE6 & I feel excited when I work intensely & $\mathbf{0 . 7 9 0}$ \\
\hline WE7 & I am proud of the work I Do &
\end{tabular}

Note: $C R=$ Composite Reliability; AVE=Average Variance of Extracted; *=significant (two-tailed test, $r<0.05$ ).

Source: Data Processing SmartPLS 3.2.8.

\subsection{Structural Model}

The coefficient determinant (R2), the test of collinearity, and hypothesis will be determined. The higher R2 value will indicate a better relationship of exogenous constructs against endogenous constructs predicted by R2. Table 2 shows that work engagement, POS, and need achievement each has R2 of 0.637, 0.519, and 0.287, respectively. It means that POS, PSS, and need achievement describe $63.7 \%$ of work engagement, and $36.3 \%$ describe another construct that was not measured in this model. The calculation also shows that PSS can explain $51.9 \%$ of the POS construct, and the rest of $48.1 \%$ should be explained by using another construct that is not included in this model. Lastly, the construct -needs achievement motivation- is described by the constructs POS and PSS $28.7 \%, 71.3 \%$, and other constructs that are not involved in this model.

Table 2. Evaluation of $R^{2}$

\begin{tabular}{|c|c|}
\hline Endogenous Constructs & $\mathbf{R}^{\mathbf{2}}$ \\
\hline Work engagement & 0.637 \\
\hline $\begin{array}{c}\text { Perceived Organizational } \\
\text { Support }\end{array}$ & 0.519 \\
\hline Need Achievement & 0.287 \\
\hline
\end{tabular}

Source: Data Analyzed (SmartPLS 3.2.8)

This research model needs to check the tendency of collinearity by calculating the Variance Inflation Factor (VIF) limit value. If there is VIF value is more than 5.0, then there is a tendency to collinearity (Sarwono and Narimawati, 2015). Table 3 shows that the value of the VIF on the model is below 5.0, so it can be concluded that there is no collinearity on the model. 
Table 3. Collinearity Evaluation

\begin{tabular}{|l|c|l|l|l|c|}
\hline \multicolumn{2}{c|}{$\begin{array}{c}\text { As Predictor work } \\
\text { engagement }\end{array}$} & \multicolumn{2}{c|}{ As Predictor POS } & \multicolumn{2}{c|}{$\begin{array}{c}\text { As Predictor } \\
\text { Need achievement }\end{array}$} \\
\hline \multicolumn{1}{|c|}{ Construct } & VIF & Construct & VIF & Construct & VIF \\
\hline POS & 2.186 & PSS & 1.000 & POS & 2.081 \\
\hline PSS & 2.210 & & & PSS & 2.081 \\
\hline Need achievement & 1.403 & \multicolumn{3}{|c|}{} & \\
\hline \multicolumn{2}{|l|}{ Remarks : POS = Perceived organizational support ; PSS=Perceived supervisor support } \\
\hline
\end{tabular}

Source: Data Analyzed (SmartPLS 3.2.8).

Subsequent hypothesis testing was conducted to find out if the influence between the construct was supported or unsupported. This research used a directional hypothesis, and a one-tailed test will test it; the critical t value will be 1.65 based on a significant level of $5 \%$, so when the calculated t value is more than 1.65 , it can be decided that the hypothesis was supported. Table 4 indicates the calculated t value of $\mathrm{H} 1, \mathrm{H} 3, \mathrm{H} 4$, H5, and H6 was higher than 1.65, so these hypotheses were supported; meanwhile, $\mathrm{H} 2$ : perceived supervisor support positively affects need achievement motivation not supported.

Table 4. Hypothesis Test Result

\begin{tabular}{|l|c|c|c|}
\hline Hypothesis & Path Coeff & t-values & Decision \\
\hline $\begin{array}{c}\mathrm{H}_{1}: \text { The POS positively effects on } \\
\text { work engagement }\end{array}$ & 0.189 & 2.878 & Supported \\
\hline $\begin{array}{c}\mathrm{H}_{2}: \text { The PSS positively affects on } \\
\text { work engagement }\end{array}$ & $\mathbf{0 . 0 4 6}$ & $\mathbf{0 . 7 8 0}$ & $\begin{array}{c}\text { Not } \\
\text { Supported }\end{array}$ \\
\hline $\begin{array}{c}\mathrm{H}_{3}: \text { The POS positively effects on } \\
\text { need achievement }\end{array}$ & 0.275 & 3.173 & Supported \\
\hline $\begin{array}{c}\mathrm{H}_{4}: \text { The PSS will positively effect on } \\
\text { need achievement motivation }\end{array}$ & 0.300 & 3.486 & Supported \\
\hline $\begin{array}{c}\mathrm{H}_{5}: \text { The need achievement positively } \\
\text { effect on work engagement }\end{array}$ & 0.656 & 13.620 & Supported \\
\hline $\begin{array}{l}\mathrm{H}_{6}: \text { The PSS a positively effect on } \\
\text { POS }\end{array}$ & 0.724 & 17.070 & Supported \\
\hline Remarks : POS = Perceived Organizational Support; PSS=Perceived Supervisor Support \\
\hline
\end{tabular}

Source: Data Analyzed (SmartPLS 3.2.8)

\section{Discussion}

The first hypotheses (H1) test result was supported that POS positively and significant effects on work engagement. It means that when employees have a good perception of the organization, they will support their work engagement. These results aligned with the previous research results of Mujiasih (2015), Murty (2017), and Najeemdeen (2018), stating that significantly and positively, POS affects work engagement, especially through cultural organizations, distributive, and procedural justice (Mujiasih, 2015). 
The second hypothesis (H2) that PSS will affect work engagement was not supported. Although associates' perception of the supervisor support was improved, work engagement was not improved. This opposite with Burns (2016), Khattak (2017), Shi and Gordon (2020) that PSS will affect work engagement; one reason is that in the educational organization, organization structure relatively flat, not so much bureaucratic, associates quickly to communicate with management no need pass through supervisors.

The third hypothesis (H3) that POS positively effects need achievement was supported means when POS was improved, associates will be motivated to achieve the best performance. This result aligns with Karami et al. (2012), Lestariningsih (2017), Chen and Shaffer (2017) that the POS positively and significantly impact the dimension of need achievement motivation, means that when as long as an organization shows good perception to the associates, they will motivate to achieve what organization and individuals targeted.

Fourth hypothesis (H4) that PSS will positively affect need achievement motivation was supported. It means that when PSS was improved, associates will be improved their motivation to achieve the best performance and goals. It also aligns with Karami and Ismail (2013), Gillet et al. (2017), London (1993), that PSS will affect need achievement motivation, when associates can behave, improvement of perceived supervisor support.

This analysis also supported the fifth hypothesis (H5) that need achievement motivation positively affect work engagement. It means that when associates improve their motivation to achieve the best performance, their work engagement will be improved. This result aligns with the research of Hsu et al. (2010) and Gillet et al. (2013) that need achievement motivation to affect work engagement.

Last, this analysis positively and significantly supported the sixth hypothesis (H6) that PSS has a positive effect on POS, it means improving PSS will impact POS, it aligns with Eisenberger et al. (2002), Burns (2016), Shi and Gordon (2020) that PSS will affect POS. This research shows that if the supervisors in this organization show higher support to associates. As a result, associates will improve perceived organizational support too.

\section{Managerial and Practical Implications}

Based on the analysis result conclusions drawn from this research, perceived organizational support would be improved when this school improves to take into account the contribution of associates to the organization by providing such reward that impact associates' welfare (special bonus, monthly achievement incentives), Outstanding achievement appreciation (visualized display for best associates in the month), do correctly pay attention to associates' welfare (periodically benchmark the remuneration with same level school), do noticing/caring about associates general 
satisfaction in the workplace, and organization show proud of associates achievements (exclusive information in the workplace).

Meanwhile, to improve perceived supervisor support, it needs to coach supervisors on how to pay attention to associates' needs without consequences and appreciate associates even in a simple way until fairness evaluation by balance scorecards. It will be better if the organization hire a psychologist as a trainee of supervisors (in this school will be headmaster for teachers, supervisors of non-teachers and directors for management) how to motivate subordinate, so the supervisors will have the appropriate method of how to manage associates and at the same time motivate the associates.

Besides that, human resources practitioners should establish programs that will impact associates' motivation to achieve the best performance that improves work engagement. The programs can be as challenging goals that link to challenging career development with outstanding bonuses and rewards, or hybrid tasks such as a teacher and management will motivate the teacher that has multitasking to reduce the boredom of teaching. The importance also is to deliver outstanding teachers to get higher education through the organization's scholarship or dispatch some nonteachers and management by a short course to adjust the knowledge by suitable topics.

\section{Theoretical Implications}

This research contributes to the relationship between perceived organizational support and perceived supervisor support against work engagement that positively and significantly mediates by need achievement motivation. Based on JD-R theory (Bakker and Demerouti, 2007), when organizations and supervisors show support to their associates by giving job resources, it needs to improve their motivation to achieve the best performance; otherwise, this improvement cannot be utilized to reduce job demand and finally cannot improve the work engagement.

This research also proved that perceived supervisor support positively, and significantly affects perceived organizational support, align with Eisenberger et al. (2002), Burns (2016), Shi, and Gordon (2020). It emphasizes that to achieve a good perceived organization from the associates, the supervisor should have well perceived the associates first.

\section{Conclusion}

Based on the results described and explained in the previous section, we could conclude that perceived organizational support and perceived supervisor support that need achievement motivation will positively and significantly affect work engagement. Perceived organizational support has positively and significantly affected work engagement directly, but perceived supervisor support does not 
directly affect it. It could also be concluded that perceived supervisor support will positively and significantly affect perceived organizational support.

\section{Limitations and Suggestions}

Several limitations existed in this research. Firstly, this research analyzed the impact of perceived organizational support and perceived supervisor support against work engagement with need achievement motivation as a mediation variable in education organization by cross-sectional methods, meanwhile motivation as a process will be interesting to research by time series. Secondly, this research was done in private education, so this research might not be generalizable to the school belong to the government. Therefore, further research about this topic was highly suggested to be conducted in a government education organization in Indonesia or other countries.

\section{References:}

Anokye, E.N., Asumeng, M.E. 2019. Psychological Capital and Achievement Motivation as Predictors of Work Engagement: A Study of Micro and Small-Scale Entrepreneurs. Ife PsychologIA, 27(2), 62-73.

Babin, B.J., James, S., Boles, J.S. 1996. The Effects of Perceived Co-Worker Involvement and Supervisor Support on Service Provider Role Stress, Performance and Job Satisfaction. Journal of Retailing, 72(1), 57-75.

Bakker, A.B., Demerouti, E. 2007. The Job Demands-Resources Model: State of the Art. Journal of Managerial Psychology, 22(3), 309-328.

Burns, K.L. 2016. Perceived Organizational Support and Perceived Supervisor Support as Antecedents of Work Engagement. San Jose State University SJSU Scholar Works, 1-57.

Chen, Y., Shaffer, M.A. 2017. The influences of perceived organizational support and motivation on self-initiated expatriates' organizational and community embeddedness. Journal of World Business 52(2), 197-208.

Deci, E.M., Ryan, R.M. 1985. Intrinsic Motivation and Self-Determination in Human Behavior. Plenum Press, New York.

Eisenberger, R., Huntington, R., Sowa, D., Hutchison, S. 1986. Perceived Organizational Support. Journal of Applied Psychology, 71(3), 500-507.

Eisenberger, R., Malone, G.P., Presson, W.D. 2016. Optimizing Perceived Organizational Support to Enhance Associate Engagement. SHRM-SIOP Science of HR Series.

Eisenberger, R., Stinglhamber, F., Vandenberghe, C., Sucharski, I.L., Rhoades, L. 2002. Perceived Supervisor Support: Contributions to Perceived Organizational Support and Associate Retention. Journal of Applied Psychology, 87(3), 565-573.

Farooqi, Y., Shaheen, A. 2014. Relationship among employee motivation, employee commitment, job involvement, employee engagement: A case study of university of Gujrat, Pakistan. International Journal of Multidisciplinary Sciences and Engineering, 5(9), 12-18.

Gillet, N., Huart, I., Colombat, P., Fouquereau, E. 2013. Perceived organizational support, motivation, and engagement among police officers. Professional Psychology: Research and Practice 44(1), 46-55.

Gülbahar, B. 2020. Investigation of the Relationship Between Perception of Supervisor Support, Perceived School Effectiveness, Work Engagement, Job Satisfaction and 
Organizational Cynic Attitude of Teachers, Participatory Educational Research 7(3), $1-20$.

Hair, J.F., Black, W., Babin, B., Anderson, R. 2010. Multivariate Data Analysis: A Global Perspective. Prentice Hall, Upper Saddle River, NJ.

Helmreich, R.L. 1983. The three faces of n-Ach. Paper presented at the meeting of the Society for Experimental Social Psychology, Pittsburgh, in Deci, E.M., Ryan, R.M., 1985. Intrinsic Motivation and Self-Determination in Human Behavior. Plenum Press, New York.

Hermans, H.J. 1970. A Questionnaire Measure of Achievement Motivation. Journal of Applied Psychology 54(4), 353-363.

Hsu, H., Chen, S., Yu, H., Lou, J. 2010. Job stress, achievement motivation and occupational burnout among male nurses. Journal of Advanced Nursing, 66(7), 1592-1601.

Jain, A. 2019. Understanding the Future of HRM Through the VUCA Lens. NHRD Network Journal, 12(2), 80-86.

Kahn, W.A. 1990. Psychological Conditions of Personal Engagement and Disengagement at Work. Academy of Management Journal, 33(4), 692-724.

Karami, R., Ismail, M. 2013. Perceived Supervisor Supports: Contribution to Aspiration, Mastery and Salience as Three Dimensions of Achievement Motivation. Middle East Journal of Scientific Research, 13(10), 1302-1311.

Karami, R., Ismail, M., Zohara, O., Wahiza, N.A.W., Badsar, M. 2012. Organizational Support and Achievement. American Journal of Applied Sciences, 9(5), 633-640.

Khattak, S.R., Batool, S., Rehman, S.U., Fayaz, M., Asif, M. 2017. The Buffering Effect of Perceived Supervisor Support on the Relationship between Work Engagement and Behavioral Outcomes. Journal of Managerial Sciences, 9(3), 20-41.

Khrisnan, J., Mary, V.S. 2012. Perceived Organizational Support- an Overview on Its Antecedents and Consequences. International Journal of Multidisciplinary Research, 2(4), 1-13.

Kottke, J., Sharafinski, C. 1988. Measuring Perceived Supervisory and Organizational Support. Educational and Psychological Measurement, 48, 1075-1079.

Kusmaryani, R.E., Widajaja, H., Siregar, J.R., Jatnika, R. 2017. Perception of Senior High School Teachers Towards School Organization Support. Cakrawala Pendidikan, 3, 458-463.

Levinson, H. 1965. Reciprocation: Between Man and Relationship Organization. Administrative Science Quarterly 9(4), 370-390.

London, M. 1993. Relationships between career motivation, empowerment, and support for career development. Journal of Occupational arid Organizational Psychology, 66, 55-63.

Makela, K. 2014. PE teachers' job satisfaction, turnover, and intention to stay or leave the profession. Unpublished doctoral dissertation, University of Jyväskylä , Finland.

Maslach, C., Wilmar, B. Schaufeli, W.B., Leiter, M.P. 2001. Job Burn-out. Annu. Rev. Psychol, 52, 397-422.

McClelland, D.C., Atkinson, J.W., Clark, R.W., Lowell, E.L. 1953. The achievement motives. In Deci, E.M., Ryan, R.M., (1985). Intrinsic Motivation and SelfDetermination in Human Behavior. Plenum Press, New York.

Murthy, R.K. 2017. Perceived organizational support and work engagement. International Journal of Applied Research, 3(5), 738-740.

Najeemdeen, I.S., Abidemi, B.T., Rahmat, F.D., Bulus, B.D. 2018. Perceived Organizational Culture and Perceived Organizational Support on Work Engagement Academic Journal of Economic Studies 4(3),199-208. 
The Relationship between Perceived Organizational, Perceived Supervisor Support, and Need Achievement to Work Engagement of School Organization

504

Putra, E.D., Cho, S., Liu, J. 2017. Extrinsic and intrinsic motivation on work engagement in the hospitality industry: Test of motivation crowding theory. Tourism and Hospitality Research, 17(2), 1-13.

Rhoades, L., Eisenberger, R. 2002. Perceived Organizational Support: A Review of the Literature. Journal of Applied Psychology, 87(4), 698-714.

Sarwono, J., Narimawati, U. 2015. Membuat Skripsi, Thesis, Dan Disertasi dengan Partial Least Square SEM (PLS-SEM). edited by Prabawati, T. Yogyakarta, Penerbit ANDI.

Schaufeli, W.B., Salanova, M., González-romá, V., Bakker, A.B. 2002. Journal of Happiness Studies, 3(1), 71-92.

Schaufeli, W.B., Bakker, A.B., Salanova, M. 2006. The Measurement of Work Engagement with a Short Questionnaire: A Cross-National Study. Educational and Psychological Measurement, 66(4), 701-716.

Schaufeli, W.B., Salanova, M. 2007.Work engagement: an emerging psychological concept and its implications for organizations. In Gilliland, S.W., Steiner, D.D. and Skarlicki, D.P. (Eds), Research in Social Issues in Management: Managing Social and Ethical Issues in Organizations, Vol 5, Information Age Publishers, Greenwich, CT.

Shi, X., Gordon, S. 2020. Organizational support versus supervisor support: The impact on hospitality managers' psychological contract and work engagement. International Journal of Hospitality Management, 87, 1-9.

Swarnalatha, C., Prasanna, T. 2012. Associate Engagement the Key to Organization. International Journal of Management, 3(3), 216-227. 